\title{
A COMPARATIVE STUDY OF LABOUR INDUCTION WITH INTRAVAGINAL MISOPROSTOL VERSUS INTRAVENOUS OXYTOCIN IN TERM PRELABOUR RUPTURE OF MEMBRANES
}

\author{
Sarika Arsekar1, Manjusha Jindal²
}

${ }^{1}$ Lecturer, Department of Obstetrics and Gynaecology, Goa Medical College, Goa, India.

${ }^{2}$ Associate Professor, Department of Obstetrics and Gynaecology, Goa Medical College, Goa, India.

ABSTRACT

\section{BACKGROUND}

Management of Term Prelabour Rupture of Membranes (PROM) remains a matter of debate despite exhaustive research.

Aims and Objectives- The objective of this study was to compare use of Tab. Misoprostol per vaginum versus Oxytocin infusion in PROM at term with respect to induction-delivery interval and maternal and foetal outcome.

\section{MATERIALS AND METHODS}

The present study was descriptive comparative study of Tab. Misoprostol (Group A) and Oxytocin infusion (Group B) for induction of labour in PROM at term. The study population consisted of 140 patients.

\section{RESULTS}

Mean induction delivery interval in present study was $541.06 \pm 186$ minutes in Group A and $556.69+219.54$ minutes in Group B ( $p=0.418$ ), showing no significant difference between two groups. 8.6\% women in Group A and 2.9\% in Group B had hyperstimulation with no significant difference between the two. There was no significant difference in neonatal complications in the two groups.

\section{CONCLUSION}

The incidences of maternal and foetal untoward effects are similar with use of the two inducing agents with no significant difference in induction delivery interval. Vaginal administration of Misoprostol in a dose of $25 \mu \mathrm{g} 6$ hourly to maximum of four doses is an effective alternative of oxytocin for labour induction in term PROM, especially in low resource set-ups where storage facility for oxytocin and skilled staff for its titration is not available.

\section{KEY WORDS}

Term Prelabour Rupture of Membranes, Oxytocin, Misoprostol, Induction of Labour.

HOW TO CITE THIS ARTICLE: Arsekar S, Jindal M. A comparative study of labour induction with intravaginal misoprostol versus intravenous oxytocin in term prelabour rupture of membranes. J. Evolution Med. Dent. Sci. 2018;7(24):2885-2888, DOI: $10.14260 /$ jemds/2018/650

\section{BACKGROUND}

Prelabour rupture of membranes (PROM) is defined as spontaneous rupture of foetal membranes occurring prior to the onset of labour. PROM occurs in about $10 \%$ of patients beyond 36 weeks of gestation.[1-3] Clinical management of PROM at term is a matter of debate. Options included expectant management and induction of labour immediately or after variable waiting period.

In modern obstetrics, as there has been the shift of focus not only from measures to reduce maternal mortality to perinatal morbidity, but also to reduce the hospital stay. Therefore, induction of labour in term PROM patients are gaining interest.

\section{MATERIALS AND METHODS \\ Design}

The study was a descriptive comparative study.

\section{Study Period}

Two years.

'Financial or Other Competing Interest': None.

Submission 09-02-2018, Peer Review 26-05-2018,

Acceptance 02-06-2018, Published 11-06-2018.

Corresponding Author:

Dr. Sarika Arsekar

Add-497/G, Canca Bandh,

Post-Parra, Bardez-453510, Goa, India.

E-mail: drsarikaarsekar@gmail.com

DOI: $10.14260 / j e m d s / 2018 / 650$

\section{Sampling}

Patients attending Goa Medical College with complaints of PROM were examined and subjects fulfilling inclusion criteria were selected for the study. Group A were the patients who received 25 micrograms of $11 / 4$ of scored tablet of 100 micrograms) Misoprostol tablet per vaginum, which was repeated 6 hourly up to 4 doses. Group B were the patients who received 3 units oxytocin in $500 \mathrm{~mL}$ of Ringer lactate solution with a starting dose of $6 \mathrm{mU} / \mathrm{min}$.

- Subjects were selected from both the groups in proportion of 1: 1 (70 patients in each group).

- Both groups were matched for age, parity and gestational age.

\section{Study Population}

Eligible patients admitted in Goa Medical College for PROM at term during 1st June 2007 to 1st June 2010. Patients who refuse to take part in the study were excluded. Prelabour rupture of membranes (PROM) was defined as spontaneous rupture of foetal membranes occurring prior to the onset of labour.

\section{Inclusion Criteria}

(1) Singleton pregnancy, (2) Gestational age of $\geq 37$ completed weeks, (3) Cephalic presentation, (4) Rupture of membranes for $\geq 6$ hrs., (6) Absence of uterine activity, (7) No known contraindication for prostaglandin use. 


\section{Exclusion Criteria}

(1) Previous caesarean delivery or other uterine surgery, (2) Suspected major degree of cephalopelvic disproportion, (3) Medical or obstetric condition complicating the pregnancy, (4) Evidence of chorioamnionitis, (5) Doubtful diagnosis of PROM.

After recruitment to the study past, present, obstetrical, menstrual history and identification data was obtained from the subjects. Detailed history regarding the leakage of the liquor and risk factor involved was taken. The period of gestation was calculated. This was followed by a thorough general clinical examination, obstetrical examination and assessment of Bishop's scoring. A sterile speculum examination was performed to confirm leakage of amniotic fluid.

\section{Ethical Issues}

Ethical clearance was sought from Hospital Ethics Committee. Besides this-

1. Written consent was taken from patients participating in the study.

2. Confidentiality was maintained.

\section{Methodology of the Study}

Subjects were selected from both the groups in proportion of 1: 1 (70 patients in each group). Both groups were matched for age, parity and gestational age. Group A were the patients who received 25 micrograms (1/4 of scored tablet of 100 micrograms) Misoprostol tablet per vaginum, which was repeated 6 hourly up to 4 doses. Group B were the patients who received 3 units oxytocin in $500 \mathrm{~mL}$ of Ringer lactate solution with a starting dose of $6 \mathrm{mU} / \mathrm{min}$. Dose was increased in step-wise manner by $6 \mathrm{mU}$ after every 30 minutes till 3 - 4 contractions lasting for 45 - 60 seconds in 10 minutes were obtained. Maximum dose administered was 30 $\mathrm{mU} / \mathrm{min}$. Patients in both the groups received same antibiotic coverage, i.e. Amoxicillin from admission till $5^{\text {th }}$ postnatal day.

In Group A, 6 hourly intervals per vaginal examination was done to assess the need for next dose. The induction was continued till maximum of 4 doses. Group B underwent vaginal examination every 4 hourly.

Failure of induction was considered when active labour did not ensue within 24 hours of induction.

Failure to progress was considered when there was no change in cervical dilatation over 2 successive vaginal examination in active phase of labour. Partogram was used for monitoring progress of labour.

\section{Statistical Analysis}

The data was analysed using SPSS version 14 for windows and the variables were compared using student's t-test (for difference between means) and $x_{2}$ test (for comparing the frequency) and value was considered significant if $\mathrm{p} \leq 0.05$.

\section{RESULTS}

Table- $1 \mathrm{a}$ and $1 \mathrm{~b}$ shows the Age and Parity distribution in both groups respectively. It is taken by convenient sample size technique since the duration of the study was 2 years. The mean age distribution of subjects in both Groups A and B were statistically similar; $p$-value $=.229$ and t-statistics 1.208 difference was not found significant.

\begin{tabular}{|c|c|c|c|c|}
\hline & $\begin{array}{c}\text { Misoprostol } \\
\text { Group } \\
\text { (N= 70) }\end{array}$ & $\begin{array}{c}\text { Oxytocin } \\
\text { Group } \\
\text { (N= 70) }\end{array}$ & $\begin{array}{c}\text { T- } \\
\text { Statistics }\end{array}$ & P-value \\
\hline Mean age & 26.74 years & 25.87 years & & \\
\cline { 1 - 3 } SD & \pm 3.72 years & \pm 4.75 years & \multirow{2}{*}{0.229} & 1.208 \\
\cline { 1 - 2 } $\begin{array}{c}\text { Minimum } \\
\text { age }\end{array}$ & 20 years & 18 years & \\
\cline { 1 - 3 } $\begin{array}{c}\text { Maximum } \\
\text { age }\end{array}$ & 36 years & 37 years & \\
\cline { 1 - 3 } \\
Tableatment Arms \\
\hline
\end{tabular}

\begin{tabular}{|c|c|c|c|c|}
\hline \multicolumn{3}{|c|}{ Parity Distribution } & \multirow[b]{2}{*}{$\begin{array}{c}\text { T- } \\
\text { Statistics }\end{array}$} & \multirow[b]{2}{*}{ P-value } \\
\hline Parity & $\begin{array}{l}\text { Misoprostol } \\
\text { Group }\end{array}$ & $\begin{array}{l}\text { Oxytocin } \\
\text { Group }\end{array}$ & & \\
\hline 0 & 49 cases & 48 cases & & \multirow{5}{*}{.9786} \\
\hline 1 & 15 cases & 14 cases & & \\
\hline 2 & 04 cases & 06 cases & & \\
\hline 3 & 01 cases & 01 cases & & \\
\hline 4 & 01 cases & 01 cases & & \\
\hline Mean & 0.43 & 0.47 & \multirow{4}{*}{0.313} & \multirow{4}{*}{0.755} \\
\hline SD & 0.79 & 0.83 & & \\
\hline Minimum & 0 & 0 & & \\
\hline Maximum & 4 & 4 & & \\
\hline Table $1 b$. & $\begin{array}{r}\text { atistical A } \\
T\end{array}$ & $\begin{array}{l}\text { sis of } P \\
\text { ment } A\end{array}$ & & Two \\
\hline
\end{tabular}

Parity also showed normal distribution (Coefficient of skewness $<3$ ). The parity distribution of subjects in both Groups A and B were statistically similar; $x_{2}=.4448$, pvalue $=.9786$, difference was not found significant and the mean of parity distribution in both the groups were also statistically similar with p-value of 0.755 .

Figure 1 and Table 2 reflects the incidence of PROM in different gestational age groups. The difference between the period of gestation of two groups was not found to be statistically significant; $x_{2}=2.2562, \mathrm{p}$-value $=.520973$. Mean POG in both the groups were also comparable as shown in Table 2 .

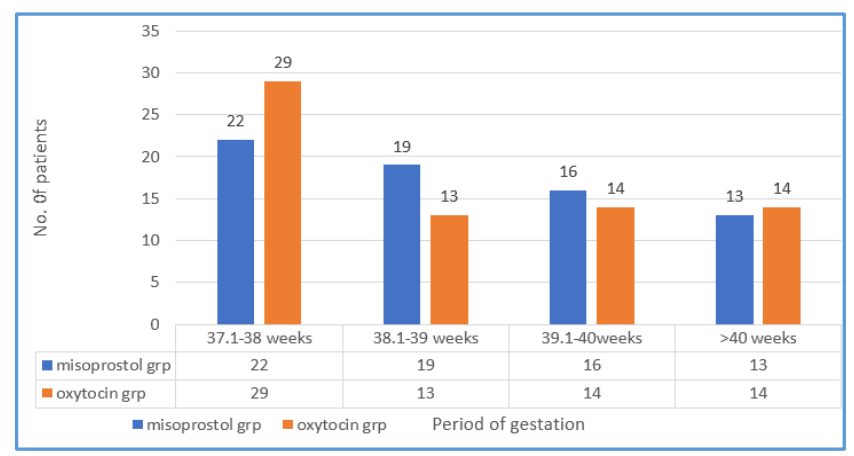

Figure 1. Period of Gestation Distribution in Two Treatment Arms

\begin{tabular}{|c|c|c|c|c|}
\hline $\mathbf{N}$ & $\begin{array}{c}\text { Misoprostol } \\
\text { Group }\end{array}$ & $\begin{array}{c}\text { Oxytocin } \\
\text { Group }\end{array}$ & $\begin{array}{c}\text { P- } \\
\text { Value }\end{array}$ & $\begin{array}{c}\text { T- } \\
\text { Statistics }\end{array}$ \\
\cline { 1 - 3 } $\begin{array}{c}\text { Mean POG } \\
\text { (Weeks) }\end{array}$ & 38.36 & 38.66 & & \\
\cline { 1 - 3 } $\begin{array}{c}\text { SD } \\
\text { (Weeks) }\end{array}$ & 0.8 & 1.10 & \multirow{2}{*}{0.07} & 1.827 \\
\cline { 1 - 2 } $\begin{array}{c}\text { Minimum POG } \\
\text { (Weeks) }\end{array}$ & 37 & 37 & & \\
\cline { 1 - 3 } $\begin{array}{c}\text { Maximum POG } \\
\text { (Weeks) }\end{array}$ & 40.3 & 41.3 & & \\
\cline { 1 - 3 } Table 2. Statistical Analysis of POG Distribution in Two \\
Treatment Arms
\end{tabular}




\begin{tabular}{|c|c|c|c|c|}
\hline $\begin{array}{c}\text { Bishops' } \\
\text { Score }\end{array}$ & $\begin{array}{c}\text { Misoprostol } \\
\text { Group }\end{array}$ & $\begin{array}{c}\text { Oxytocin } \\
\text { Group }\end{array}$ & $\begin{array}{c}\text { T- } \\
\text { Statistics }\end{array}$ & $\begin{array}{c}\text { P- } \\
\text { Value }\end{array}$ \\
\hline$\leq 2$ & 0 & 2 cases $(2.85 \%)$ & & \\
\cline { 1 - 3 } $3-5$ & $\begin{array}{c}56 \text { cases } \\
(80 \%)\end{array}$ & $\begin{array}{c}59 \text { cases } \\
(84.28 \%)\end{array}$ & \multirow{2}{*}{1.110} & \multirow{2}{*}{0.269} \\
$\geq 6$ & $\begin{array}{c}14 \text { cases } \\
(20 \%)\end{array}$ & 09 cases $(12.85)$ & & \\
\cline { 1 - 3 } Mean & $4.8 \pm 0.844$ & $4.97 \pm 0.978$ & & \\
\hline
\end{tabular}

Table 3. Distribution of Cases under both Drugs according to pre-induction Bishop's Score

The Table- 3 reveals distribution of cases under both drugs according to pre-induction Bishop's score. The mean Bishop's score in both the groups were calculated and the difference was found to be statistically insignificant with $\mathrm{p}$ value $=0.269$.

\begin{tabular}{|c|c|c|c|c|}
\hline $\begin{array}{l}\text { Duration of } \\
\text { Induction } \\
\text { Delivery } \\
\text { Interval }\end{array}$ & $\begin{array}{c}\text { Misoprostol } \\
\text { Group }\end{array}$ & $\begin{array}{l}\text { Oxytocin } \\
\text { Group }\end{array}$ & P-Value & $\begin{array}{c}\text { T- } \\
\text { Statistics }\end{array}$ \\
\hline $\mathbf{N}$ & 70 & 70 & \multirow{6}{*}{0.756} & \multirow{6}{*}{0.311} \\
\hline$\leq 12$ hours & $\begin{array}{c}54 \text { cases } \\
(77.14 \%) \\
\end{array}$ & $\begin{array}{c}48 \text { cases } \\
(68.57 \%) \\
\end{array}$ & & \\
\hline $\begin{array}{c}>12 \text { to } \leq 24 \\
\text { hours }\end{array}$ & $\begin{array}{c}13 \text { cases } \\
(18.57 \%)\end{array}$ & $\begin{array}{l}20 \text { cases } \\
(28.57 \%)\end{array}$ & & \\
\hline$>24$ hours & $\begin{array}{l}3 \text { cases } \\
(4.3 \%)\end{array}$ & $\begin{array}{c}2 \text { cases } \\
(2.86 \%)\end{array}$ & & \\
\hline $\begin{array}{c}\text { Mean duration } \\
\text { in minutes }\end{array}$ & 545.49 & 555.60 & & \\
\hline $\begin{array}{l}\text { Standard } \\
\text { deviation }\end{array}$ & 206.49 & 216.32 & & \\
\hline Table 4. St & (1) & $f M t$ & 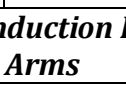 & \\
\hline
\end{tabular}

It was observed that the mean induction delivery interval with misoprostol was 545.49 and with oxytocin was 555.60 and this difference was statistically insignificant using standard error of difference between two means.

\begin{tabular}{|c|c|c|c|}
\hline $\begin{array}{c}\text { Mode of } \\
\text { Delivery }\end{array}$ & $\begin{array}{c}\text { Misoprostol } \\
\text { Group }\end{array}$ & $\begin{array}{c}\text { Oxytocin } \\
\text { Group }\end{array}$ & $\begin{array}{c}\text { P- } \\
\text { value }\end{array}$ \\
\cline { 1 - 3 } $\begin{array}{c}\text { Spontaneous } \\
\text { vaginal delivery }\end{array}$ & $\begin{array}{c}58 \text { cases } \\
(82.85 \%)\end{array}$ & $\begin{array}{c}58 \text { cases } \\
(82.85 \%)\end{array}$ & \\
\cline { 1 - 3 } Forceps & 3 cases $(4.28 \%)$ & 2 cases $(2.85 \%)$ & \multirow{2}{*}{0.683} \\
\cline { 1 - 3 } Vacuum extraction & 1 case $(1.42 \%)$ & 1 case $(1.42 \%)$ & \\
\cline { 1 - 3 } Caesarean section & $\begin{array}{c}8 \text { cases } \\
(11.42 \%)\end{array}$ & $\begin{array}{c}9 \text { cases } \\
(12.85 \%)\end{array}$ & \\
\cline { 1 - 4 } \\
Treatment Arms
\end{tabular}

As shown in Table-4, there was no statistically significant difference between both the groups regarding mode of delivery.

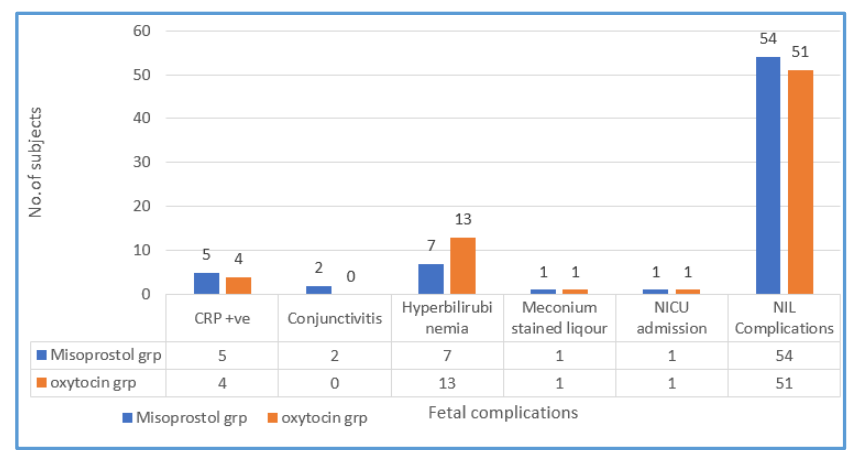

Figure 2. Comparison of Foetal Complications in Two Treatment Arms
Comparison of foetal complications in two treatment arms showed $73 \%$ of babies born to the oxytocin group and $77 \%$ of those born to misoprostol group did not develop any complication. The proportion of those who required NICU admission and developed meconium stained liquor was same in both the groups. None of the neonates in oxytocin group developed conjunctivitis. The difference with respect to the complications was not statistically significant $(p>0.05)$.

\begin{tabular}{|c|c|c|}
\hline Complications & $\begin{array}{c}\text { Misoprostol } \\
\text { Group }\end{array}$ & $\begin{array}{c}\text { Oxytocin } \\
\text { Group }\end{array}$ \\
\hline Hyperstimulation & 6 cases (8.6\%) & 2 cases (2.9\%) \\
\hline Fever & 0 case & 4 cases $(5.7 \%)$ \\
\hline Nil complication & 64 cases (91.4\%) & 63 cases (90\%) \\
\hline \multicolumn{2}{|c|}{ Table 6. Maternal Complication } \\
\hline \multicolumn{2}{|c}{}
\end{tabular}

The difference in the occurrence of complication was not statistically significant ( $p>0.05$ ), though hyperstimulation occurred in 6 cases (8.6\%). There were no complications attributed to prostaglandin in misoprostol group like fever, nausea, vomiting etc.

\section{DISCUSSION}

The management of PROM has covered a long journey of controversies and confusions over the years which includes expectant management, delayed induction, immediate induction, method of induction and continues till date. Wing and Paul et $\mathrm{al}^{4}$ had mean induction delivery interval in misoprostol and oxytocin group of $811.5 \pm 511.4$ mins and $747 \pm 448$ mins respectively. In spite of induction delivery time being 64.5 mins more in misoprostol group, there was no significant difference between the induction delivery interval of the two groups ( $\mathrm{p}=0.87$ ). Overall mean induction delivery interval in Wing and Paul ${ }^{4}$ study is more than the current study, as their study included subjects with less favourable Bishops' score than ours.

Most of the previous studies had used the dose of misoprostol as $50 \mu \mathrm{g}$. In a study by Datta Rath, 5 while comparing the induction delivery interval it was seen that the duration is more in misoprostol group compared to oxytocin. Frohn et $\mathrm{al}^{6}$ and AA Ayad ${ }^{7}$ had compared misoprostol with $\mathrm{PGE}_{2}$. Their induction delivery interval in misoprostol group is more than in current study, but in comparison to $\mathrm{PGE}_{2}$ it was less which shows that misoprostol is more effective inducing agent than $\mathrm{PGE}_{2}$. Ozden et $\mathrm{al}^{8}$ with a dose of $50 \mu \mathrm{g}$ had similar induction delivery interval as present study, but he had used oxytocin after 24 hours of expectant management. In spite of expectant management, oxytocin group had a longer induction delivery interval ( $\mathrm{p}=.0005)$.

In study by Frohn et al $^{6}$ longer induction delivery interval can be explained due to lower mean gestational age, i.e. $36.2 \pm 3.1$ weeks. In study by AA Ayad, ${ }^{7}$ the probable cause of longer induction delivery interval is not known as they have not specified the anthropometric criteria used in their study.

In spite of using a conservative dose of $25 \mu \mathrm{g} 6$ hourly, the mean induction delivery interval in misoprostol group was less than oxytocin group (with no significant difference) in the present study.

\section{CONCLUSION}

Current study was a prospective cohort study comparing two drugs, i.e. $25 \mu \mathrm{g}$ vaginally administered Misoprostol and intravenous Oxytocin for induction of labour in term 
prelabour rupture of membranes. The incidences of maternal and foetal untoward effects are similar with use of the two inducing agents with no significant difference in induction delivery interval. Vaginal administration of Misoprostol in a dose of $25 \mu \mathrm{g} 6$ hourly to maximum of four doses is an effective alternative of oxytocin for labour induction in term prelabour rupture of membranes, especially in low resource set-ups where storage facility for oxytocin and skilled staff for its titration are not available.

\section{REFERENCES}

[1] Polzin WJ, Brady K. The etiology of premature rupture of membranes. Clin Obstet Gynecol 1998;41(4):810-6.

[2] Duff P, Huff RW, Gibbs RS. Management of premature rupture of membranes and unfavorable cervix in term pregnancy. Obstet Gynecol 1984;63(5):697-702.

[3] Conway DI, Prendiville WJ, Morris A, et al. Management of spontaneous rupture of the membranes in the absence of labor in primigravid woman at term. Am J Obstet Gynecol 1984;150(8):947-51.
[4] Wing DA, Paul RH. Inductions of labor with misoprostol for premature rupture of the membranes beyond 36 weeks gestation. Am J Obstet Gynecol 1998;179(1):94-9.

[5] Rath DM, Manas K. Induction of labor with oral misoprostol in women with prelabor rupture of the membranes at term. J Obstet Gynecol India 2007;57(6):505-8.

[6] Frohn WE, Simmons S, Carlan SJ. Prostaglandin E2 gel versus misoprostol for cervical ripening in patients with premature rupture of the membranes after 34 weeks. Obstet Gynecol 2002;99(2):206-10.

[7] Ayad IAA. Vaginal misoprostol in managing premature rupture of the membranes. East Mediterr Health J 2002;8(4-5):515-20.

[8] Ozden S, Delikara MN, Avci A, et al. Intravaginal misoprostol vs. expectant management in premature rupture of membranes with low Bishops score at term. Int J Gynaecol Obstet 2002;77(2):109-15. 